The Editor will be pleased to receive for publication papers or notes dealing with any insects which are of economic importance. Such communications to be addressed to

\title{
THE DIRECTOR,
}

$$
\text { Imperial Bureau of Entomology, }
$$

British Museum (Natural History),

London, S.w.

Subscriptions for the "Bulletin of Entomological Research" should be sent to

$$
\begin{aligned}
& \text { Messrs, DULAU \& Co., Ltd., } \\
& \text { 37, Soho Square, London, w. }
\end{aligned}
$$

The annual subscription is Ten Shillings, post free. 


\section{CONTENTS.}

\section{ORIGINAL ARTICLES.}

PAGE

Distaxt, W. L. Notes on Some Injurious African Rhynchota

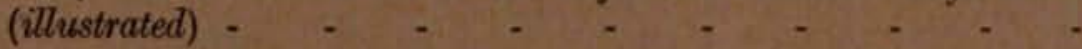

DURrant, John Harti.ex. A New Cotton-seed Moth (Mometa zemiodes) from West Africa - _ _ _ _ _ - 243

GreEn, E. Ernest. Remarks on a Small Collection of Coceidae from Northern Australia (illustrated) - - - .

Hampson, Sir George F. Two New Species of Wood-boring Moths from West Africa

Hirst, Stanlexy. On the Parasitic Acari found on the Species of Rodents frequenting Human Habitations in Egypt (illustrated) - - - - - - - - - .

Krng, HaRoLD H. Further Notes on the Bionomies of Tabanus ditaeniatus, Maeq., and Tabamus taeniola, P. de B. (Plate XXVI)

LAMBorn, Dr. W. A. The Agrieultural Pests of the Southern Provinces, Nigeria (Plates XVII-XXV) - - - .

Marshall, GuY A. K. Four New Injurious Weevils from Africa (illustrated)

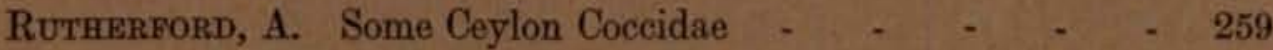
WATERSTON, JAMES. Notes on African Chalcidoidea-I (illustrated) 249

\section{MISCELLANE0US.}

Collections received 